\title{
IRRIGATION VOLUME AND FREQUENCY AND TREE SIZE AFFECT ESTABLISHMENT RATE
}

\author{
by Edward F. Gilman, Robert J. Black, and Bijan Dehgan
}

\begin{abstract}
Irrigation volume had no effect on post-transplant trunk diameter growth, crown spread, height growth, or stem xylem potential of Quercus virginiana (live oak) in the first 27 months after transplanting. Container-grown trees irrigated infrequently after transplanting grew more slowly than those irrigated frequently and more slowly than field-grown trees. This resulted from increased water stress on container trees that were infrequently irrigated. Post-transplant growth of trees from a field nursery was not affected by irrigation frequency. Three of 30 trees on the infrequent irrigation schedule, which were transplanted from containers, died the 1st time irrigation was cut back from twice each week to once a week 7 weeks after transplanting, and new, nonlignified shoot and leaf tissue on most other container trees dried up. No trees transplanted from the field nursery died, nor did new growth wither. The 1st year after transplanting, trunk diameters of trees collected from the wild increased more slowly than those of trees transplanted from containers or from the field. However, growth of trees from containers increased more slowly than for trees from the other 2 production methods during the 2nd and 3rd year after transplanting. During the first 27 months after transplanting, trunk diameter and tree height increased faster on smallsized nursery trees of live oak than on large-sized trees. Rate of trunk diameter growth for container trees slowed the 2nd growing season on large-sized container trees, perhaps because roots were not fully established in landscape soil. Frequently irrigated trees established more quickly than those receiving infrequent irrigation.
\end{abstract}

A number of studies compared growth of trees transplanted from different nursery production methods. Hensley (1993) found that green ash (Fraxinus pennsy/vanica) transplanted into clay soil from either in-ground fabric containers (Grobags) or bare root grew as well as trees from a traditional-sized balled and burlapped (B\&B) soil root ball. Freshly dug trees grown in fabric containers were more water stressed after transplanting into a sandy soil than B\&B trees or those from plastic containers (Harris and Gilman 1991). Slash pine (Pinus elliottii) from plastic containers established more slowly than trees from fabric containers or field-grown plants (Beeson and Gilman 1992a).
Trees of laurel oak (Quercus laurifolia) and East Palatka holly (Ilex x attenuata 'East Palatka') grown above ground in plastic containers and transplanted into the landscape were more stressed and grew more slowly than B\&B trees if irrigation was limited after transplanting (Gilman and Beeson 1996a). This has been attributed to rapid drying of the substrate by increased root surface area in container root balls compared to B\&B root balls (Nelms and Spomer 1983; Harris and Gilman 1993; Gilman and Beeson 1996b). Little work has been performed on live oak (Quercus virginiana), the most commonly planted tree in Florida, and a popular shade tree in many other regions in USDA hardiness zones 8-11.

The objectives of this study were: 1) to determine the influence of irrigation volume and frequency on live oak for the first 27 months following transplanting; 2) to compare posttransplant growth and stress on trees collected from the wild with that of field-grown and container-grown plants 33 months after transplanting; and 3) to compare post-transplant growth rate of small caliper trees with that of larger trees for 3 years after transplanting.

\section{Materials and Methods}

Experiment one: Irrigation volume and frequency. Sixty live oak with a $6 \mathrm{~cm}(2.5 \mathrm{in}$.) trunk diameter (caliper) measured $15 \mathrm{~cm}(6 \mathrm{in}$.) from the ground from \#25 containers, and $60 \mathrm{~B} \& \mathrm{~B}$ trees with a $6.5 \mathrm{~cm}$ (2.7 in.) caliper (AAN 1996) were planted on $6 \mathrm{~m}$ ( $20 \mathrm{ft}$ ) centers February 26 through 29, 1992, into a Millhopper fine sand (loamy, silicaous, hyperthermic Grossarenic Paleudults) in USDA hardiness zone 8b in Gainesville, Florida. Data were collected for 27 months after transplanting. Planting holes were twice as wide as the root ball. The top of the root ball was placed even with the surrounding soil, and no soil was spread over the root ball. Backfill soil was not 
amended. B\&B trees had been dug 6 months earlier and placed inside $71 \mathrm{~cm}$ (28 in.) diameter wire baskets lined with burlap and held in full sun in the same position as in the field nursery. All trees planted from containers were staked to stabilize them in the soil. B\&B trees were not staked because their root balls were heavy enough to keep them from blowing over. A $2 \mathrm{~m}(6 \mathrm{ft})$ wide strip centered on the tree was maintained weed free with periodic applications of glyphosate (Roundup). A $5 \mathrm{~cm}$ (2 in.) layer of baldcypress (Taxodium distichum) mulch was placed on a $3.24 \mathrm{~m}^{2}\left(36 \mathrm{ft}^{2}\right)$ square area around each tree. Trees from each production method (container and $B \& B)$ were irrigated with 11,22 , or $33 L(3,6$, or 9 gal) of water either frequently or infrequently $(2 x$ $3 \times 2$ factorial) in a randomized complete block design with 1 replication per block in 10 blocks for a total of 120 trees. Rainfall amounts at the site in 1992 were $12.7 \mathrm{~cm}$ (5.0 in.) for March (normal = $3.3 \mathrm{in}$.), $10.4 \mathrm{~cm}$ (4.1 in.) for April (normal = $2.0 \mathrm{in}$.), $4.8 \mathrm{~cm}$ (1.9 in.) for May (normal = $3.1 \mathrm{in}$.) $16.8 \mathrm{~cm}$ (6.6 in.) for June (normal $=6.8 \mathrm{in}.), 14.0 \mathrm{~cm}(5.5 \mathrm{in}$.) for July (normal = $6.8 \mathrm{in}$.), $22.1 \mathrm{~cm}(8.7 \mathrm{in}$.) for August (normal $=8.3 \mathrm{in}$.), and $10.7 \mathrm{~cm}$ (4.2 in.) for September (normal= $5.5 \mathrm{in}$.). Irrigation for each tree was delivered through micro-irrigation spray stakes that applied water in a spray pattern over the root ball only.

All 120 trees were irrigated daily with 55 to $74 \mathrm{~L}$ (15 to $20 \mathrm{gal}$ ) the 1 st week after transplanting (WAT). During the 2nd WAT, all trees received daily irrigation at 11, 22, or $33 \mathrm{~L}$. Beginning March 15,1992 (2 WAT), trees on the frequent irrigation schedule received 11,22 , or $33 \mathrm{~L}$ daily through week 13 (May 25), then every-other-day irrigation for 8 weeks, then weekly irrigation July 15 through September 30 , then no irrigation for 30 weeks. Beginning March 15, 1992, trees infrequently irrigated received 11,22 , or $33 L$ twice each week for 8 weeks (through May 8, 1992), then weekly for 3 weeks, then no irrigation. Irrigation was withheld from all infrequently irrigated trees during the 7th, 11th, and 12th WATs so that stem xylem potential ( $\Psi$ stem) could be measured under water-stressed conditions and compared to measurements made on trees that were not water stressed (i.e., frequently irrigated trees).
Ammonium nitrate was surface applied to a square $9.9 \mathrm{~m}^{3}\left(100 \mathrm{ft}^{2}\right)$ area around each tree 3 times each year at a rate of $1 \mathrm{lb} \mathrm{N} / 1,000 \mathrm{ft}^{2}$.

Stem xylem potential was measured with a pressure chamber (Soil Moisture Equipment, Inc., Santa Barbara, California) infrequently on 5 to 7 $\mathrm{cm}$ ( 2 to 3 in.) long current-year twigs with foliage from the sunny side of the canopy. Cumulated water stress in MPa-hr (SW) was estimated for each diurnal stem xylem potential curve by calculating the area above the curve to $0 \mathrm{Mpa}$ and then taking the absolute value (Beeson and Gilman 1992a). Trunk diameter $30 \mathrm{~cm}$ (12 in.) from the ground, branch crown spread, and tree height were measured at transplanting and throughout the 28-month post-transplanting portion of the study. A visual estimate of the percent of current-year twig length without foliage was recorded for all 120 trees independently by the authors at 11 and 26 WAT. Current-year twigs without foliage meant that the twig elongated with foliage in the spring but leaves later dropped from the twig, or the twig was dead. Visual estimate data were analyzed on each date as an average of the 2 independent estimates.

The number of dead trees was recorded for each treatment. Dead trees were not included in the analysis of growth data. Growth and stress data were analyzed with a 3-way ANOVA as a randomized complete block design. The t-test was used to evaluate equality of slopes.

Experiment two: Irrigation frequency and production methods. Sexually propagated trees of live oak were planted in a sandy field soil in November 1987, in a central Florida nursery from \#1 [3 L (.8 gal)] containers and were drip irrigated, fertilized frequently, and root pruned at least yearly inside of what became the root ball at harvest. Ten of these field-grown trees averaging $9.9 \mathrm{~cm}$ (3.9 in.) trunk diameter were dug in late January 1992 with a $1 \mathrm{~m}$ (40 in.) tree spade in accordance with industry standards (ANN 1996) and placed inside wire baskets lined with coppertreated burlap. Trees were irrigated daily and held at the nursery until May 1992, when they were shipped $56 \mathrm{~km}$ (35 miles) to the planting site in Gainesville, Florida (USDA hardiness zone 8b). At another central Florida nursery, sexually 
propagated live oak were produced in black plastic containers above ground in a sand, bark, and peat substrate. Final container size was 246 $\mathrm{L}$ (65 gal), and trees averaged $8.9 \mathrm{~cm}$ (3.5 in.) trunk diameter. At a 3rd nursery in central Florida, 10 trees of live oak averaging $9.3 \mathrm{~cm}$ (3.6 in.) trunk diameter were collected from the wild in early February 1992 with a $1 \mathrm{~m}$ (40 in.) tree spade, placed inside wire baskets lined with coppertreated burlap, irrigated daily, and held at the nursery (i.e., they were not nursery grown). Trees were shipped about $56 \mathrm{~km}$ (35 miles) to the planting site in Gainesville, Florida. All 30 trees averaged $9.4 \mathrm{~cm}$ (3.7 in.) trunk diameter and were planted in the research field May 26, 1992, into a Millhopper fine sand. Trees from containers required staking to stabilize them in the soil. Five trees of each treatment were irrigated frequently, and 5 were irrigated infrequently (described below). Trees were arranged $6 \mathrm{~m}(20 \mathrm{ft})$ apart in a 3 production method $x 2$ irrigation frequencies factorial in a randomized complete block design, with 1 tree from the 6 treatment combinations in each of 5 blocks. Wood chip mulch of baldcypress was placed on a $3.24 \mathrm{~m}^{2}\left(36 \mathrm{ft}^{2}\right)$ square area around each tree. Ammonium nitrate was surface applied to a square $9.9 \mathrm{~m}^{2}\left(100 \mathrm{ft}^{2}\right)$ area around each tree, 3 times each year at a rate of $1 \mathrm{lb}$ $\mathrm{N} / 1,000 \mathrm{ft}^{2}$.

Beginning the day of planting (May 26, 1992), all trees were irrigated daily with $37 \mathrm{~L}(10 \mathrm{gal})$ in the morning and $37 \mathrm{~L}$ in the afternoon applied over the root ball for the first 2 WAT. Frequently irrigated trees received $74 \mathrm{~L}(20 \mathrm{gal})$ irrigation daily in the morning through October 26, 1992, then every other day through December 3 (41 WAT), then no irrigation. Beginning June 10, 1992 , infrequently irrigated trees received $74 \mathrm{~L}$ in the morning every other day through July 4 , then every 3rd day through August 24 (26 WAT), then irrigation was discontinued. Trunk diameter at $30 \mathrm{~cm}$ (12 in.) above the soil and tree height were measured at planting and at periodic intervals throughout the study. Diurnal stem xylem potential was measured infrequently on 5 to 7 $\mathrm{cm}$ ( 2 to 3 in.) long current-year twigs with foliage from the sunny side of the canopy. Cumulated

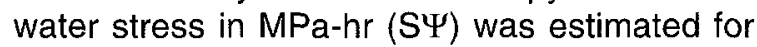

each diurnal stem xylem potential curve by calculating the area above the curve to $0 \mathrm{Mpa}$ and then taking the absolute value (Beeson and Gilman 1992a). The study was terminated in March 1995.

Growth and water stress data were analyzed with a 2-way ANOVA as a randomized complete block design. The t-test was used to evaluate equality of slopes.

\section{Results and Discussion}

Experiment one: Irrigation volume and frequency. Irrigation volume did not interact with production method or irrigation frequency. Averaged across production method and irrigation frequency, irrigation volume had no effect on posttransplant trunk diameter growth, crown spread, height growth, or stem xylem potential (data not shown). This suggests that $1.2 \mathrm{~L} / \mathrm{cm}(1.2 \mathrm{gal} / \mathrm{in}$.) of trunk diameter was the maximum volume needed to promote good growth after transplanting into the sandy soil at the planting site. Applying more volume would be wasteful. Unpublished research by the authors on larger live oaks suggests that trees can survive on $1 \mathrm{~L} /$ $\mathrm{cm}$ (1 gal/in.) of trunk diameter.

Averaged across irrigation frequency and volume, there was no difference in height growth or crown spread between surviving trees from containers and those from the field in the 2 years following transplanting (data not shown). However, the interaction between production method and irrigation frequency was significant (at $P=0.01$ ) for trunk diameter growth (Figure 1), indicating that during the first 7 months after transplanting, container trees irrigated infrequently grew more slowly than all other trees. By 9 months after transplanting, trunk diameter growth rates were equal among all treatments, indicating that trees were equally established.

As with laurel oak and East Palatka holly (Gilman and Beeson 1996a), slowed growth probably resulted from increased water stress on container trees infrequently irrigated (Figure 2, 12 WAT). Increased water stress has been shown to be the result of slow root growth in trees transplanted from containers, as compared to field-grown trees (Beeson and Gilman 1992b). 
Although infrequently irrigated field-grown trees were also more stressed than those frequently irrigated 12 WAT, the difference in stress was significantly greater for container-grown trees $(P$ $=0.01)$. In addition, xylem potential on stressed container trees was greater than $-2.0 \mathrm{MPa}$ for several hours 12 WAT and on other dates (data not shown). Photosynthesis is greatly reduced at this level of water stress in live oak (Beeson and Gilman 1992b).

There was no difference in stem xylem potential between production methods 7 WAT, and there was no interaction between production method and irrigation frequency (Figure 2). Frequently irrigated trees of both production methods on all measuring dates were less stressed, as indicated by a smaller area (less S $\Psi$ ) under the diurnal xylem potential curves (Figure 2). Frequent irrigation coincided with more trunk diameter growth for trees transplanted from containers but not for those from the field nursery (Figure 1). Crown spread and tree height also

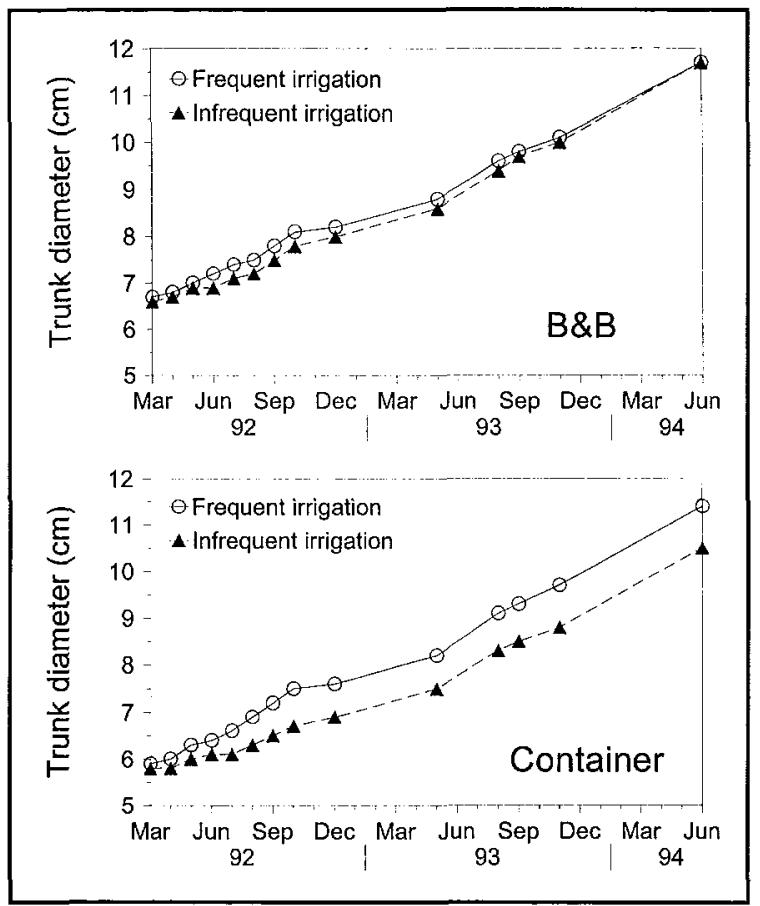

Figure 1. Trunk diameter growth on trees transplanted from $B \& B$ and containers either frequently or infrequently irrigated. Each point is the mean of 30 trees. increased $(P<0.01)$ more for trees in both production methods frequently irrigated than for those infrequently irrigated (data not shown). Marshall and Gilman (1997) found that root growth 3 years after transplanting also increased with frequent irrigation for container-grown trees but not for field-grown trees, and field-grown trees had greater root cross-sectional area than trees planted from containers.

Three of 30 trees on the infrequent irrigation schedule that were transplanted from containers died (previous year's leaves were brown and hanging on the twigs; new leaves and shoots were dried up) the 1st time irrigation was cut back from twice each week to once a week (7 WAT), and new, nonlignified shoot and leaf tissue on most other container trees also dried up. No trees transplanted from the field nursery died, nor did new growth wither. As a result of this dry period, trees from containers had a larger percentage of twigs without foliage than did the field-grown trees during the first 6 months after planting (Figure 3 ).

These data show that field-grown trees of live oak, harvested several months before transplanting to a landscape, were more tolerant of dry soil conditions after transplanting that those from containers. Similar data have been generated for laurel oak, East Palatka holly (Gilman and Beeson 1996a), and slash pine (Beeson and Gilman 1992a). Greater stress has been attributed to greater root density and drainage from the root ball after planting a container tree compared to a B\&B tree. In an apparent contradiction, Harris and Gilman (1993) indicated that container-grown trees were less stressed after planting than were trees from the field. However, that comparison was performed on freshly dug field-grown trees purposefully placed under water-deficit conditions immediately after digging. The current study used field-grown trees dug from the field several months prior to transplanting and irrigated frequently in the nursery before planting into the landscape. These so-called "hardened off" trees (Gilman 1997) appear superior to others perhaps due to the leaf loss that occurs in the weeks after digging and the new roots generated through the burlap in the months after digging. If these roots are not 
damaged during shipping and planting, they provide immediate contact with backfill soil once planted. Leaf loss, root regeneration, and perhaps osmotic adjustment (Beeson and Gilman 1992b) provide a favorable combination for successful transplanting of hardened-off field-grown trees.

Experiment two: Irrigation frequency and production method. There was no interaction between production method and irrigation frequency. Averaged across irrigation frequency, trunk diameter on trees collected from the wild increased more slowly (t-test, $P<0.01$ ) than on trees transplanted from containers or from the field the 1st growing season after transplanting (Figure 4). This may be due to the lesser root weight inside the root ball on trees from the wild compared to such root weight in nursery-grown trees (Gilman et al. 1992). Trunk diameter on trees from containers increased more slowly $(P$ $<0.01$ ) than on trees from the other 2 production methods the 2nd and 3rd years after transplanting. In the 1st year after transplanting, trees from all 3 production methods grew faster $(P<0.01)$ when irrigated frequently for the first 41 WAT than when infrequently irrigated for the first 26 WAT (data not shown). There was a less pronounced effect $(P=0.05)$ on growth of irrigation frequency the 2nd year after transplanting and no effect the $3 \mathrm{rd}$ year. Because trees were not irrigated past 26 WAT (August 30 , 1992) for infrequently irrigated trees and 41 WAT (December 3,1992 ) for frequently irrigated trees, the 2nd-year effect may have been a carryover from the 1st-year irrigation treatment. In the first 28 months after transplanting, trees from the field nursery $(P<0.01)$ and collected trees $(P=0.07)$
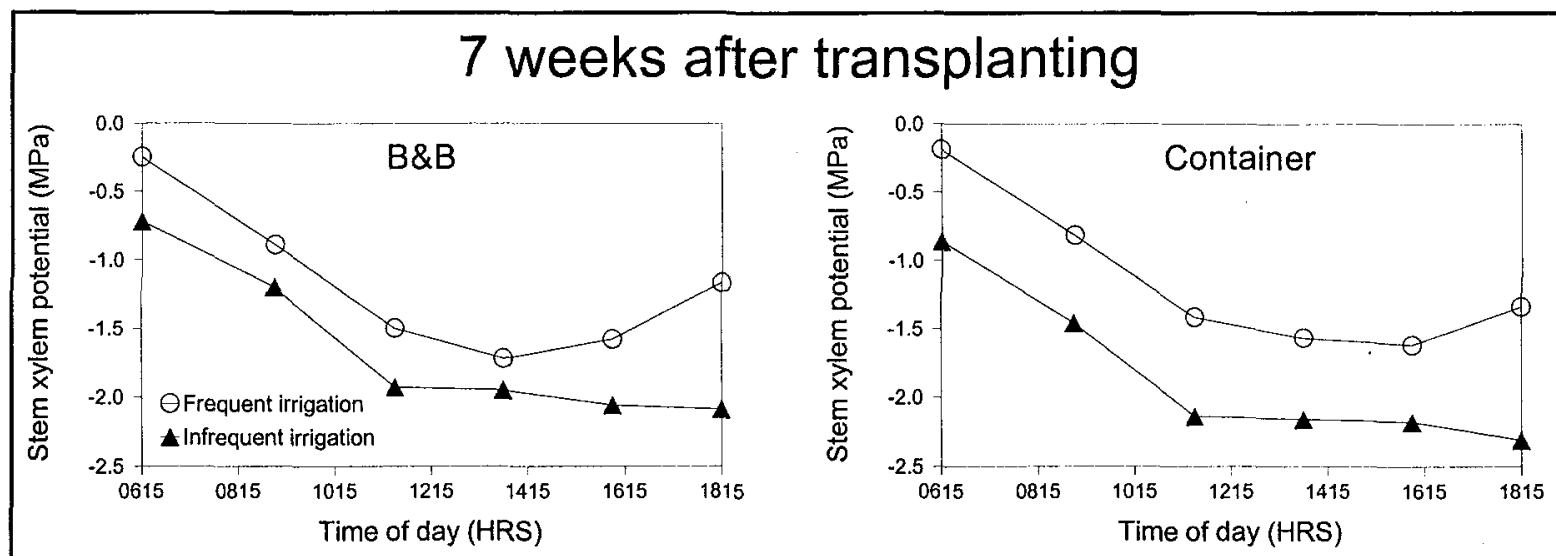

\section{2 weeks after transplanting}
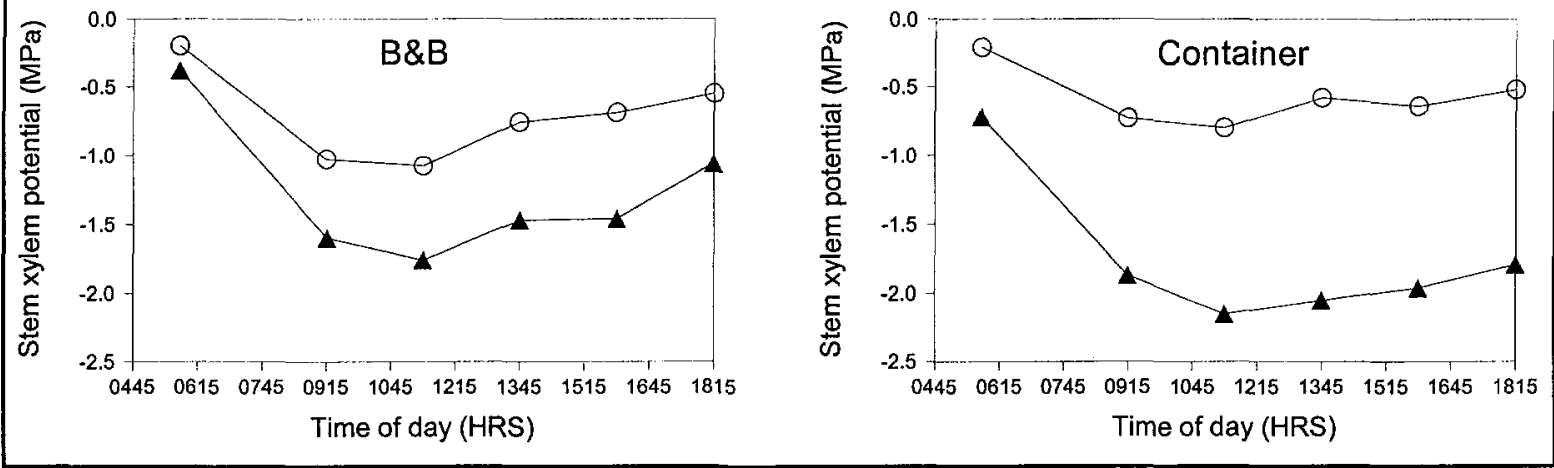

Figure 2. Stem xylem potential 7 and 12 weeks after transplanting B\&B or container-grown trees. Each point is the mean of 10 trees. 
increased in height $[1.03 \mathrm{~m}$ and $0.91 \mathrm{~m}(3.4 \mathrm{ft}$ and $3 \mathrm{ft}$, respectively] more than those planted from containers $[0.51 \mathrm{~m}(1.7 \mathrm{ft})]$.

All trees received irrigation twice daily the 1st WAT, but on the 7th day after planting, half the trees from each production method were not watered until after sundown. Stem xylem potential (S $)$ during the 7 th day was more negative $(P<$ $0.05)$, indicating greater water stress than experienced by the trees that received $37 \mathrm{~L}(10$ gal) in the morning and $37 \mathrm{~L}$ in the afternoon on the day they were measured (Figure 5). Containergrown trees were less stressed on this day than were trees from other production methods. There was no interaction for $S \Psi$ between production method and irrigation. One week later (2 WAT), water on all 30 trees was turned off for 2 days and diurnal xylem potential was measured throughout the 2 nd day. On this 14th day after transplanting, xylem potential decreased (more stress) more quickly for container trees than for collected and field-grown trees (data not shown). For example, 6 of 10 container trees had xylem potential less than $-2.0 \mathrm{MPa}$ at 11:30 $\mathrm{hr}$, whereas only 1 collected tree and 1 field-grown tree had xylem potential less than -2.0 MPa. The data from these first 2 dry-down periods indicate that during the first 2 WAT, container root balls hold enough water to keep live oak xylem potential above $-2.0 \mathrm{MPa}$ for only 1 day, whereas soil root balls (B\&B) had a larger supply or used it more slowly. During the

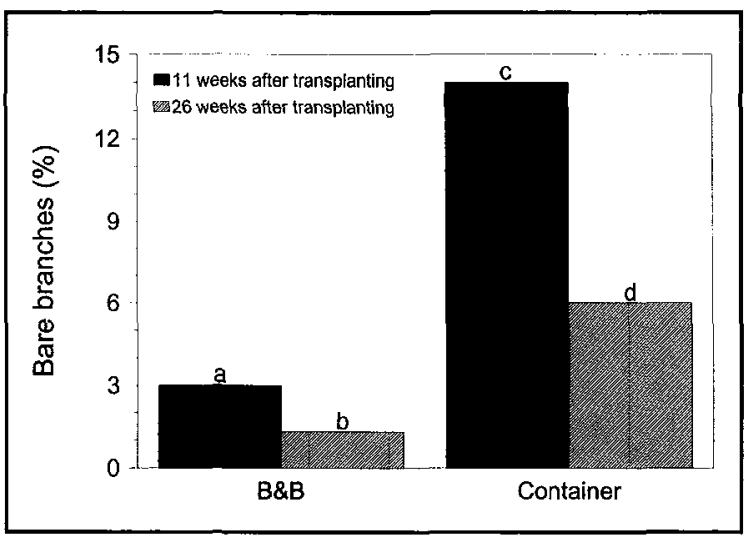

Figure 3. Percent of current year twig length without foliage. Each bar is the mean of 60 trees. 2nd dry day, xylem potentials in container trees in the current study were sufficiently low beginning in the morning and continuing all afternoon to reduce photosynthesis (Beeson and Gilman 1992b); this was not the case for collected and field-grown plants. Nelms and Spomer (1983) also found that container root balls had less than a 1day supply of available moisture in the summer.

At 6 WAT, stem xylem potential averaged across production methods during a 2nd day without irrigation on infrequently irrigated trees was significantly greater $(P<0.05)$ than on frequently irrigated trees that received irrigation that morning (Figure 5). This probably resulted from more root growth into the backfill soil in irrigated trees (Marshall 1997). Container trees were more stressed on the last reading of the day than were collected and field-grown trees, but there were no differences in xylem potential among production methods during the earlier part of the day. Container-grown, infrequently irrigated trees were more stressed $(P=0.06)$ (greater $S \Psi$ ) 21 WAT (October 20) than were the trees grown by other production methods. Infrequently irrigated trees were more stressed than those that were irrigated daily. There were no differences in stem xylem potential among production methods or irrigation frequencies, and the interaction was not significant 55 WAT.

At 42 WAT (March 1993), the so-called "stormof-the-century" moved through the study plots

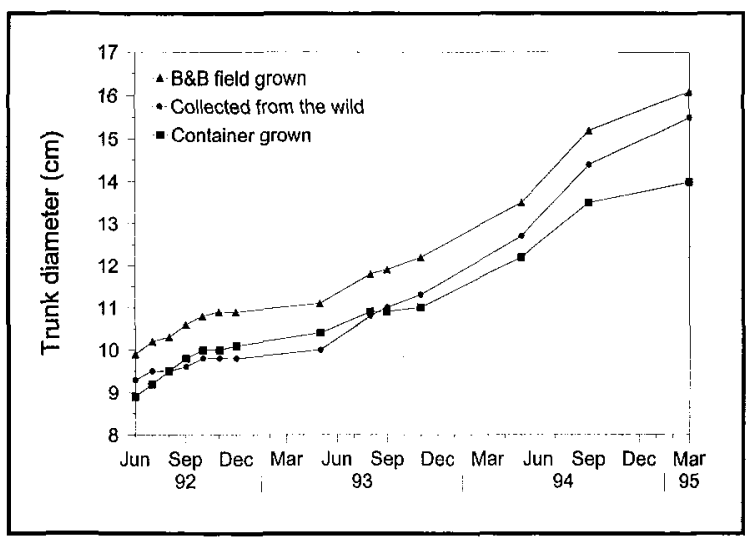

Figure 4. Trunk diameter growth after transplanting trees from B\&B, collected, and containers. Each point is the mean of 10 trees. 
with strong winds and driving rain. Due to the strong winds, leaves turned necrotic and crispy on most trees planted from containers that were in the infrequently irrigated plots, whereas few collected or field-grown trees sustained this injury. This might indicate that roots were not as well established for container-grown trees as they were for trees from the other 2 production methods. This hypothesis is supported by other work (Blessing and Dana 1987; Gilman and Beeson 1996a; Marshall 1997) that indicates root growth is slower from trees planted from containers than from those transplanted from field nurseries. Two studies showed no difference in root growth between the two production methods (Harris and Gilman 1993; Laiche et al. 1983).

Comparison of large and small trees. During the 27 months after transplanting, trunk diameter
(Figure 6) and tree height (Figure 7) increased faster $(P<0.01)$ on small-sized nursery trees of live oak than on large-sized trees. Lauderdale (1995) also found that small trees outgrew larger ones, but there was little difference in growth rate for willow oak. The rate of trunk diameter growth for container trees slowed significantly $(P<0.01)$ the 2nd growing season on large-sized trees [246 $L$ (65 gal)] perhaps because roots were not fully established in landscape soil. Smaller field-grown trees establish quickly because roots come into balance with shoots sooner than they do for larger trees (Watson 1985) and for container-grown trees (Beeson and Gilman 1992a; Gilman and Beeson 1996). Slower root growth may be responsible for reduced shoot growth rate on container-grown trees the 2nd year, especially because trees were not irrigated the 2 nd year.
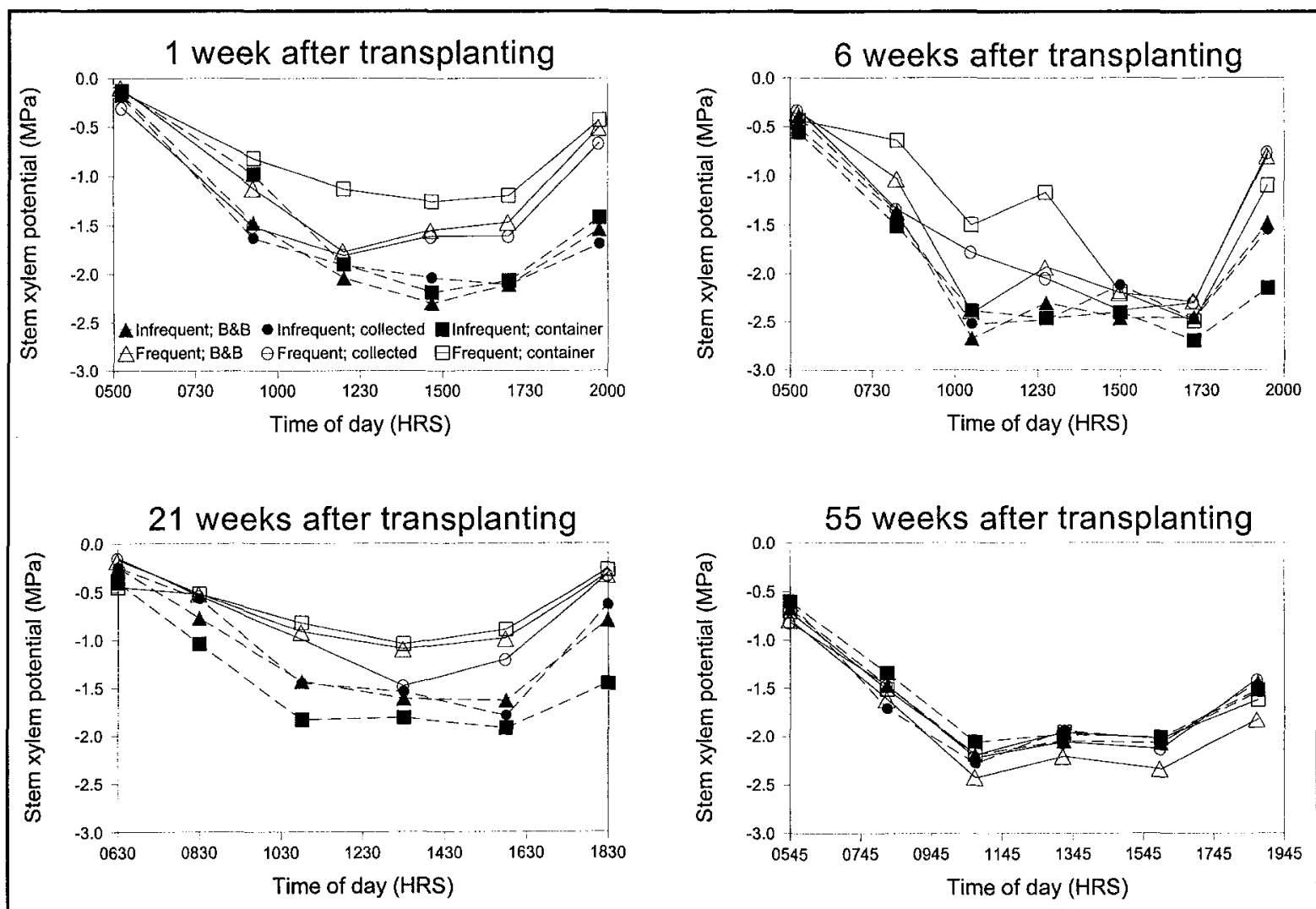

Figure 5. Stem xylem potential 1, 6, 21 and 55 weeks after transplanting trees from B\&B, collected, and containers, either frequently or infrequently irrigated. Each point is the mean of 7 trees. 


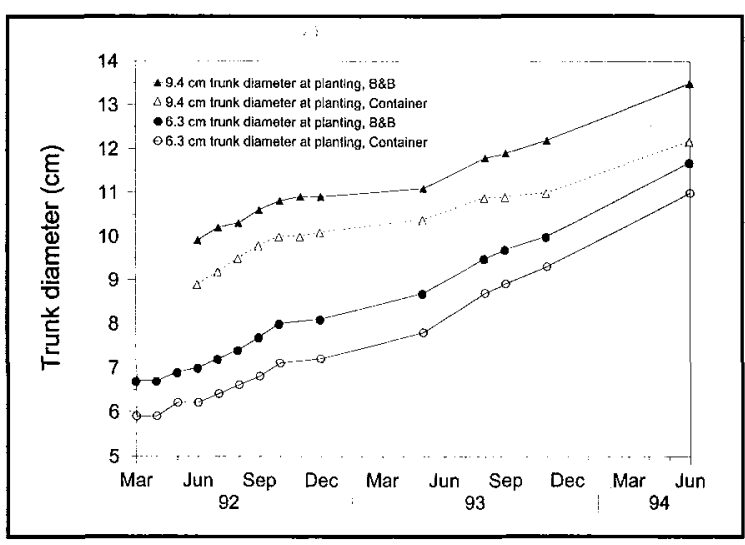

Figure 6. Trunk diameter after transplanting smalland large-diameter trees from B\&B or containers. Each point is the mean of 10 replicates (larger trees) or of 60 replicates (smaller trees).

\section{Conclusions}

Transplanted trees did not need to be irrigated outside the original root ball to establish quickly. A larger volume of water did not compensate for irrigating infrequently (i.e., it was more important to irrigate transplanted trees frequently than it was to apply a large volume of water). No more than $1.2 \mathrm{~L}$ irrigation per $\mathrm{cm}$ ( $1.2 \mathrm{gal} / \mathrm{in}$.) of trunk diameter was needed to promote good growth on live oak trees after transplanting. Frequent irrigation during the 1st growing season after transplanting was more beneficial than infrequent irrigation because it promoted survival and rapid establishment. Hardened-off field-grown live oak trees, harvested several months before transplanting to a landscape, appear more tolerant of dry soil conditions after transplanting than container-grown trees. Container-grown trees were more likely to succumb to desiccation than were hardened-off B\&B trees. Trees collected from the wild grew more slowly the 1st year after transplanting, but in the following 2 years grew at a same rate as B\&B trees from a field nursery. All surviving trees from all production methods looked nearly identical at the conclusion of the study 28 months after transplanting and would probably be considered of equal quality by most observers. Small nursery trees grew faster after transplanting than larger ones because roots came into balance with shoots sooner.

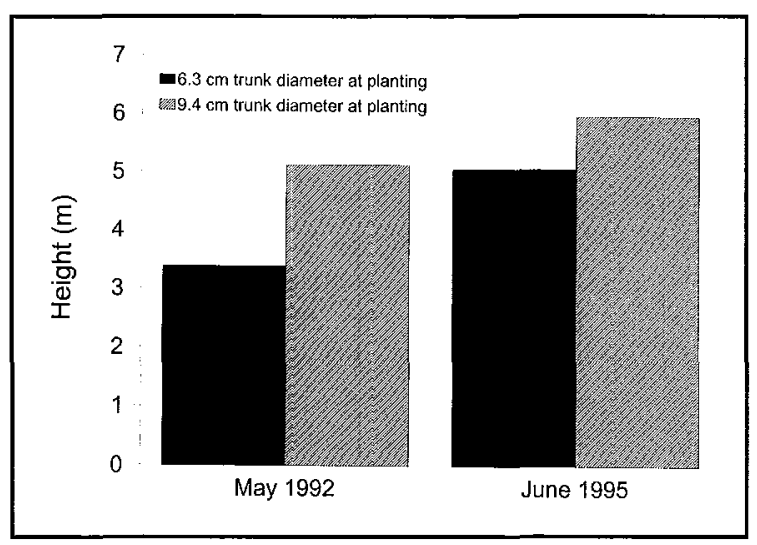

Figure 7. Initial and final height of small- and largecaliper trees. Each bar is the mean of 10 trees.

Acknowledgments. The authors wish to thank Stewart's Tree Farm and Marshall Tree Farm for their support in conducting this project.

\section{Literature Cited}

American Association of Nurserymen. 1990. American standard for nursery stock.

Beeson, R.C., Jr., and E.F. Gilman. 1992a. Diurnal water stress during landscape establishment of slash pine differs among three production methods. J. Arboric. 18:281-287.

Beeson, R.C., Jr., and E.F. Gilman. 1992b. Water stress and osmotic adjustment during post-digging acclimatization of Quercus virginiana produced in fabric containers. J. Environ. Hort. 10:208-214.

Blessing, S.C., and M.N. Dana. 1987. Post-transplant root system expansion in Juniperus chinensis $L$. as influenced by production system, mechanical root disruption and soil type. J. Environ. Hort. 5:155-158.

Gilman, E.F. 1997. Trees for Urban and Suburban Landscapes. Delmar Publishers, Albany, NY. 662 pp.

Gilman, E.F., and R.C. Beeson, Jr. 1996a. Production method affects tree establishment in the landscape. J. Environ. Hort. 14:81-87.

Gilman, E.F., and R.C. Beeson, Jr. 1996b. Nursery production method affects root growth. J. Environ. Hort. 14:88-91.

Gilman, E.F., R.C. Beeson, Jr., and R.J. Black. 1992. Comparing root balls on laurel oak transplanted from the wild with those of nursery and container grown trees. J. Arboric. 18:124-29. 
Harris, J.R., and E.F. Gilman. 1991. Production method affects growth and root regeneration of Leyland cypress, laurel oak and slash pine. J. Arboric. 17:64-69.

Harris, J.R., and E.F. Gilman. 1993. Production method affects growth and post-transplant establishment of 'East Palatka' holly. J. Amer. Soc. Hort. Sci. 118:194-200.

Hensley, D.L. 1993. Harvest method has no influence on growth of transplanted green ash. J. Arboric. 11:379-382.

Laiche, A.J., G.S. Cobb, and R.B. Reed. 1983. Root and shoot growth of field- and container-grown pecan nursery trees five years after planting. HortScience 18:328-329.

Lauderdale, D.M. 1995. Tree transplant size influences post-transplant performance. Masters Thesis, Auburn University.

Marshall, M.E. 1997. Effect of production methods on root morphology, transplanting, and establishment of landscape trees. Masters Thesis, University of Florida.

Marshall, M.E., and E F. Gilman. 1997. Production method and irrigation affect root morphology of live oak. J. Environ. Hort. 15:84-87.

Nelms, L.R., and L.A. Spomer. 1983. Water retention of container soil transplanted into ground beds. HortScience 18:863-866.

Watson, G.W. 1985. Tree size affects root regeneration and top growth after transplanting. J. Arboric. $11: 37-40$.

Environmental Horticulture Department University of Florida Gainesville, FL 32611
Zusammenfassung. Die Menge der Bewässerung hat nach dem Verpflanzen von Quercus virginiana keinen Einfluß auf das Dickenwachstum des Stammes, die Kronenbreite, das Höhenwachstum oder das Stammxylempotential. Containerpflanzen, die unregelmäßig bewässert werden, wachsen langsamer als regelmäßig gewässerte Bäume und auch langsamer als Freilandbäume. Das Wachstum der Bäume aus einer Baumschule nach dem Verpflanzen wurde nicht durch die Bewässerungshäufigkeit beeinflußt. Drei von 30 Bäumen aus der unregelmäßigen Bewässerung, die aus Containern verpflanzt wurden, starben nach sieben Wochen, nachdem die erste Bewässerung von zweimal pro Woche auf einmal pro Woche reduziert wurde. Auch neue, nicht verholzte Triebe und Blätter von den anderen Bäumen vertrockneten. Keiner der Bäume aus der Baumschule starb oder zeigte Welkeerscheinungen. Im ersten Jahr nach dem Verpflanzen war der Wachstumsanstieg im Stammdurchmesser bei wildgewachsenen Bäumen kleiner als bei Container-oder Freilandbäumen. Trotzdem wuchsen Containerbäume im zweiten und dritten Jahr nach der Verpflanzung langsamer als Bäume aus den zwei anderen Aufzuchtmethoden. Der Stammdurchmesser und die Höhe nahm schneller bei kleinerer Baumschulware zu als bei größerer. Die Zuwachsrate des Stammdurchmesser bei größeren Bäumen verlangsamte sich in der zweiten Wachstumsperiode. Regelmäßig bewässerte Bäume establierten sich schneller als die nur gelegentlich bewässerten Bäume. 